\title{
Ellipsis
}

2015

\section{Misadventures on a Saturday Night}

Amy Soileau

University of New Orleans

Follow this and additional works at: https://scholarworks.uno.edu/ellipsis

\section{Recommended Citation}

Soileau, Amy (2015) "Misadventures on a Saturday Night," Ellipsis: Vol. 42 , Article 2.

DOI: https://doi.org/10.46428/ejail.42.02

Available at: https://scholarworks.uno.edu/ellipsis/vol42/iss1/2

This Creative Nonfiction is brought to you for free and open access by the Department of English and Foreign Languages at ScholarWorks@UNO. It has been accepted for inclusion in Ellipsis by an authorized editor of ScholarWorks@UNO. For more information, please contact scholarworks@uno.edu. 


\title{
Misadventures on a Saturday Night
}

\author{
Amy Soileau
}

God is going to punish you. My mother's voice rang like a little bell in the back of my mind as we hooked a left on to Maine Street. It was a warm and humid night, the sky starless and bearded with violet clouds. Four of us were sardined into a single-cab truck. The stench of gasoline fumes and over-lubricated hormones overpowered anything else. Hesitantly I checked the time, and the radioactive glow on the dashboard hypnotized me. It read 12:30.

"You okay?" Erica asked.

I looked up at her and watched as her freckles budded then faded with every passing street light.

"Yep," I said with a weak smile. Erica, my best friend of eight years, was always a bloodhound to my nervous nature. She attempted to comfort me by patting the back of my hand. I remarked to myself how Erica, who stood barely five feet tall, was easily the most daring and fearless person I had ever met. Her most redeeming quality, however, was her ability to tolerate my cricket of a conscious. I checked to see if the two boys noticed what was going on, and, to my relief, they were distracted. Sebby was messing with the radio on his country music pilgrimage, while Ryan was trying to tame the elusive stick-shift. He pulled out a can of chewing tobacco from his one-size-too-small jean pocket and tried to shift into third gear. The truck jerked and groaned.

"Smooth like butter, baby," he said, placing a pinch of tobacco into his mouth.

My eyes darted at him, then at the stick-shift, then at him again.

"Are you sure you know how to drive this thing?" I asked. "I mean, you've done this before right?"

"All the time, been driving since I was thirteen," he said.

"And where did you get this truck again?"

Ryan ignored my question and tongued the lump of tobacco inside his bottom lip. It resembled an inoperable tumor.

"Look, I go all the way out to pick y'all up, and all you're gonna do is ask questions? I can drop y'all back any time if there's a problem," he said.

"Oh, shush. She's just trying to talk to you," Erica boomed.

I rolled my eyes and allowed the sharp twangs of a banjo from a song I didn't recognize to fill the silence. We turned at the corner of an abandoned Wal-Mart parking lot. I watched as the town of Ville Platte's scrunched-up wooden houses were replaced with a wilderness of thick pine trees. The sleek asphalt beneath the truck's tires was replaced with rough gravel, and the streetlamps disappeared leaving only the truck's headlights to guide our way.

"Say man, let me drive," Sebby said, after a few minutes in our new terrain. 
Ryan found a narrow opening between the gridlocked trees and drove onto an empty cow field. My gut twisted as I looked through the rear window and saw only the red glow of brake lights staining the darkness. Unfazed, Sebby slid into the driver's seat and shifted into reverse. The wheels moved beneath us, but the truck remained perfectly still.

"It must be bogged from all that rain over the last few days," Ryan said. He spit the rest of his chewing tobacco into an empty Mountain Dew can. "I'll go out and give it a push."

Ryan was out front pushing with all of his force, while Sebby gunned the gas pedal. The wheels screeched and smoked, but we didn't budge.

"Try to drive up a bit, maybe that'll help," Ryan yelled.

The truck lurched forward before getting stuck in an even bigger mud puddle in the middle of the field. My pulse galloped in my throat as all the color drained from my face.

Ryan gestured for Sebby to get out of the truck. The two boys huddled together, whispering back and forth.

"Look," Ryan said. "Me and Sebby are going walk to see if there's somebody who can help us."

"Are you crazy? You can't just leave us out here alone," I said, with tears dewing in my eyes.

"Oh, stop being so scared. There's nothing out here that can hurt y'all. Just stay in the truck and leave the headlights on," Ryan said.

Erica's eyebrows were knitted and a look of disbelief scribbled across her face. Sebby shrugged and joined Ryan without a word. They slinked away from the stranded vehicle into a solid curtain of darkness, like a ventriloquist and his dummy exiting a show. As soon as the boys were out of sight, Erica and I plunged into each other's arms.

"It's okay. It'll all be fine," Erica said. It was obvious she was trying to hide the tremor in her voice. "I'm so sorry, Amy. I'm so sorry I got us into this mess. I'm sure they'll find someone."

"There is no one...we are miles from town! What freak of nature would be out at this time and all the way out here?"

Erica smashed the knob on the radio and didn't reply. I steeped in the silence and felt the weight of my own question, realizing the truth it held.

God's punishing me. This time the voice was deafening and my own. The Catholic guilt, which started as a seedling when I was a child, had now erupted into a full-blown oak. I was convinced this was my penance for sneaking out to ride in a possibly stolen truck with two untrustworthy boys we met from the roller-rink last week-two boys who weren't all that cute anyway. I wondered if my mother was still snoring in bed, blissfully unaware of what her heathen of a daughter was up to. Or if she was furiously awake cursing my name in Cajun French and alerting the National Guard. Up until this point, I had always shrugged off her forewarnings of a vengeful God, believing it was just a scare tactic to make naughty children behave. I looked at Erica with welts of tears in my eyes. She was blank-faced and staring down into her lap. I was about to say something to her-anything — when I saw Ryan walking up to the truck. 
"What I told you girls, we found somebody to pull us out," Ryan said, as I rolled down the window.

"Yeah, don't ever doubt my boy again," Sebby said, tip-toeing to pat Ryan's shoulder.

I turned around and noticed a new pair of headlights beaming through the darkness. They were from an oversized truck with a growling diesel engine. I was able to make out a balding, middle-aged man with a hairy arm bowed out the window.

"His name's Bucky," Ryan said, waving at the man. "He was on a beer run and saw us walking."

Bucky, I thought, the hillbilly guardian angel.

"Tie her up, boys," Bucky said. He pulled out a bottle of Budweiser and toasted to us. "Let's make it quick, the wife's waiting on me."

Ryan returned to the driver's seat, and after a few tugs we were finally back on the gravel road. A million questions buzzed through my mind but were quieted by my dire want to go home. Ryan waved to thank Bucky, and we sped back towards town. The blacktop cushioned the tires, and the entirety of the drive home was solemn. Everyone seemed to focus on how the tiny houses replaced the dense trees. As we neared our street, I forced Ryan to drop us off a block away. We told the boys a weak goodbye and jumped out.

Erica and I didn't say much to each other. At the time, I think neither of us fully processed what just happened. A cooling drizzle began to fall as we rounded my salmoncolored brick house. We were nearing the back porch when my eyes caught the pink blur of my mother's robe going past the large dining room window. I felt woozy, and the muscles, which were starting to relax, knotted up again. Erica eyes widened, and a trembling hand covered her mouth. My mother walked outside with the screen door slamming behind her. There was an unlit cigarette wedged between her lips. It was too late to hide.

"I just went in the room to check on y'all. Do you have any idea that it's after two in the morning?" she asked, lighting the cigarette. "What in the hell are y'all doing?"

"Nothing...I just dared us to go outside," I said.

"Uh huh," she said. Her voice was strained and raspy.

We joined her on the porch. My dampened clothes clung to my sore limbs. At this point, all I wanted was to go inside, rip up Ryan's number in my diary, and go to bed. "Hey!" my mother yelled into the empty yard. "If there are any boys out there, I'm calling the cops!"

"Mom stop. Nobody's there," I said.

I headed for the door with Erica trailing behind me. My mother's hand smelled like an ashtray as it reached out and grabbed my shoulder.

"Fine," Mom said. She looked me up and down, as if trying to find some type of incriminating evidence. "Just know that if you did do something wrong, God will punish you." 